\title{
Determinanty silnej pozycji rynkowej marek handlowych
}

https://doi.org/10.33141/po.2005.04.01

Jacek Kall
Przegląd Organizacji, Nr 4 (783), 2005, ss. 10-13 www.przegladorganizacji.pl Towarzystwo Naukowe Organizacji i Kierownictwa (TNOiK)
Oferowanie przez sieci detaliczne marek handlowych jest jednym z możliwych sposobów uzyskiwania przez nie przewagi konkurencyjnej. Sukcesy niektórych detalistów, jakie osiągnęli na tym polu (choćby kanadyjska sieć Loblaw z jej marką prywatną President's Choice) uzasadniają bliższą analizę zjawiska, jakim są marki handlowe.

Silna pozycja rynkowa marek handlowych jest zjawiskiem notowanym głównie w najwyżej rozwiniętych krajach świata. Liderzy (Szwajcaria, Wielka Brytania) charakteryzują się udziałem rynkowym marek handlowych na poziomie 30-40\% (w ujęciu wartościowym), zaś w kolejnych pięciu badanych przez AC Nielsen krajach (Niemcy, Belgia, Hiszpania, Francja i Ka-

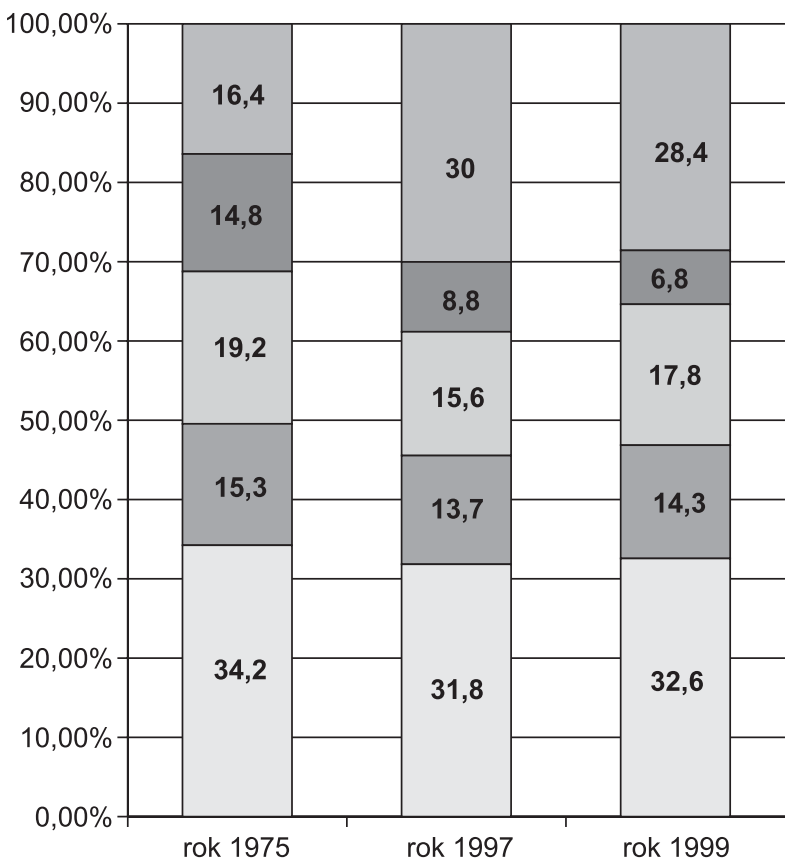

$$
\begin{aligned}
& \square \text { marki należące do sieci } \square \text { marki poniżej } 2 \% \\
& \square \text { pozostałe marki }>2 \% \text { udziałów rynkowych } \\
& \square \text { marka numer } 2 \quad \square \text { lider rynku }
\end{aligned}
$$

Rys. Struktura typowego rynku dóbr częstego zakupu w Wielkiej Brytanii w latach 1975, 1997 oraz 1999

Źródło: Customer Loyalty \& Private Label Products, KPMG Global Consumer Markets, marzec 2000; M. CAMPBELL, Trying Times: The Impact of Media and Promotions, „An Information Resources White Paper", maj 2002, s. 3. nada) udział rynkowy marek handlowych przekracza 20\%. Zdecydowanie zaznacza się przy tym dominacja Europy Zachodniej i Ameryki Północnej, które koncentrują aż 95\% światowej sprzedaży marek handlowych (8 z 10 krajów o najwyższym udziale marek handlowych to kraje europejskie) ${ }^{1}$. Przy okazji warto zauważyć, że w obrębie dużych rynków (jak na przykład północnoamerykański), w poszczególnych regionach metropolitarnych pozycja rynkowa marek handlowych bywa mocno zróżnicowana ${ }^{2}$.

Nie wdając się w spory metodologiczne odnośnie do sposobu ustalania udziału marek handlowych w rynku (które powodują, że w przypadku Polski wielkości podawane przez różne agencje badawcze są znacząco różne), warto zwrócić uwagę na fakt, potwierdzany przez wszystkie instytucje badawcze, $\mathrm{i}$ to na różnych rynkach - udział marek handlowych jest mocno zróżnicowany pomiędzy poszczególnymi kategoriami produktowymi.

Zarówno na rynku amerykańskim ${ }^{3)}$, jak i brytyjskim (zob. rysunek) ekspansja marek handlowych dokonuje się zwykle kosztem słabszych marek producentów - marki handlowe oraz wiodące marki producentów na każdym rynku produktowym wydają się koegzystować w swoistej symbiozie.

Wśród czynników, które sprzyjają osiąganiu przez marki handlowe silnej pozycji i wypieraniu $\mathrm{z}$ rynku słabszych marek producentów wymienia się zwykle ${ }^{4)}$ : - penetrację przez marki handlowe różnych kategorii produktowych, co umożliwia im silniejsze oddziaływanie na konsumentów;

- pełniejszą kontrolę, jaką nad markami handlowymi mają detaliści (jakość, opakowanie, merchandising);

- korzystanie przez marki handlowe z ruchu konsumentów w sklepie, generowanego przez reklamy wiodących marek producentów;

- zagwarantowane pełne pokrycie sieci oraz dobrą lokalizację na półce (niższe koszty marketingowe);

- fakt, że marek handlowych nie dotyka często spotykane w przypadku marek producentów zjawisko „zakupów na zapas” czy „przerzutów” do innych regionów.

Pogłębiona analiza czynników sprzyjających osiąganiu przez marki handlowe znaczących udziałów rynkowych powinna uwzględnić trzy grupy podmiotów mogących mieć wpływ na ich sukces, a mianowicie konsumentów kupujących te marki; produktów, jakim one towarzyszą oraz samych sieci detalicznych, których są własnością. 
W przypadku konsumentów zauważalna jest koncentracja zakupów marek handlowych w stosunkowo nielicznym segmencie nabywców. Co prawda, marki handlowe kupowane są przez większość konsumentów, a prawidłowość ta zauważalna jest na różnych rynkach geograficznych ${ }^{5}$, ale niewielkie grono ich entuzjastów (np. w USA 1/4 kupujących je w największych ilościach) generuje nadproporcjonalnie duży popyt ( $51 \%$ sprzedaży) na nie. Segment kupujących marki handlowe w dużych ilościach poddany był licznym analizom, ale większość elementów opisu tych konsumentów nie pokrywa się ${ }^{6}$. Wydaje się jak najbardziej uzasadnione skoncentrowanie się raczej na cechach osobowości tych konsumentów, a nie ich opisie demograficznym (tab. 1).

Niektórzy autorzy sugerują, że zgodnie z naturalnymi tendencjami rozwoju rynków, udział marek handlowych w obrotach każdą kategorią produktowa stabilizuje się naturalną koleją rzeczy na poziomie 30-35\% - barierą wzrostu miałaby być niezagrożona pozycja wiodacych marek producentów, które zawsze będą poszukiwane przez sporą część konsumentów. Wobec takich oczekiwań nabywców detaliści dbający o wrażenie szerokiego wyboru nie mogą ograniczać oferty wyłącznie do marek handlowych. Sugeruje się także, że przekroczenie progu 30-35\% udziału marek handlowych w kategorii produktu wzmaga presję na producentów, która w nieunikniony sposób prowadzi

Tab. 1. Wyróżniki segmentu intensywnych nabywców marek handlowych

- rosnace poczucie niezależności konsumentów-mogą kupować co chcą i gdzie chcą,

- rosnące oczekiwania w zakresie elastyczności, wygody i wyboru w trakcie zakupów oraz w ramach kupowanych produktów,

- większe poczucie bezpieczeństwa (słabo odczuwane ryzyko zakupowe) - dokonywanie łatwych wyborów opartych na rozróżnianiu między ofertami pod względem cen i jakości,

- postrzegana przez nabywce zdolność do oceny marki wyłącznie na podstawie informacji zawartych na opakowaniu (nie występuje potrzeba poszukiwania dodatkowych informacji),

- mniejsza wrażliwość na jakość lub postrzeganie marek handlowych jako dorównujących markom producentów pod względem funkcjonalności,

- ograniczony czas na dokonanie zakupu,

- przeznaczenie kupowanego produktu - głównie do codziennego użytku (nie jako prezenty),

- marginalizowanie ryzyka związanego $\mathrm{z}$ wizerunkiem własnym (które mogłoby być następstwem zakupu marki handlowej),

- mniejsze znaczenie zewnętrznych źródeł w procesie poszukiwania informacji.

- postrzeganie detalisty jako racjonalnego i zasługującego na zaufanie,

- konsument dysponuje wiedzą o markach handlowych oraz doświadczeniami związanymi z ich zakupem.

Źródło: J.A. QUELCH, D. HARDING, op.cit., s. 48-50; R. BATRA, I. SINHA, Consumer-Level Factors Moderating the Success of Private Label Brands, „Journal of Retailing”, lato 2000; P.S. RICHARDSON, K. Jain ARUN, A. DICK, Household Store Brand Proneness: A Framework, „Journal of Retailing”, 2/1996. do spadku ich budżetów marketingowych oraz inwestycji w nowe produkty, co z kolei stanowi istotne ograniczenie w dostępie do źródeł zaopatrzenia ${ }^{7}$.

Generalnie jednak zauważa się tendencję do opanowywania przez marki handlowe kilku wybranych kategorii produktów, z reguły masowych, rzadko niszowych (w skali światowej najwyższe udziały marek handlowych notuje się w przypadku gotowych dań mrożonych, folii aluminiowej do żywności, mleka, warzyw mrożonych oraz konserwowych, frytek, mrożonych ryb i owoców morza - we wszystkich tych produktach marki handlowe maja co najmniej $1 / 3 \mathrm{rynku}^{8)}$ ). Zasięg produktowy wykorzystania marek handlowych zdaje się być ograniczony motywacją konsumenta do zakupu - w przypadku dóbr o silnym ładunku symbolicznym wykreowanie silnej marki należącej do detalisty jest znacznie trudniejsze w porównaniu z produktami czysto użytkowymi. Marki handlowe mają zatem słabą pozycję w takich kategoriach, jak mleko w proszku dla niemowląt, dania gotowe dla niemowląt, guma do żucia, piwo, dezodoranty, szminki, mleczko do twarzy, pasta do zębów, płyny po goleniu ${ }^{9}$.

Jak wykazują badania własne autora ${ }^{10)}$, zdecydowana większość polskich nabywców marek handlowych (ok. 3/4) wykazuje obawy przed nabyciem każdego, dowolnego produktu zaoferowanego pod marka handlową ${ }^{11)}$. Oczywiście, w przypadku różnych sieci

Tab. 2. Czynniki związane z produktem, sprzyjające dominującej pozycji marki detalisty

- produkt prosty, niedrogi, łatwy do wyprodukowania, na podstawie masowych (niemarkowych) surowców, półfabrykatów, przy nieskomplikowanym procesie produkcyjnym,

- branżę charakteryzuje duża nadwyżka mocy produkcyjnych, przy czym dominują drobni oraz średniej wielkości producenci,

- produkt łatwo psujący się, co faworyzuje lokalnych dostawców,

- sprzedaż produktu jest wysoka i stale rośnie,

- marki producentów oferowane sa w niewielu odmianach, wariantach, co stwarza markom handlowym okazję do zaprezentowania sie jako wyraźna alternatywa dla nich, - nikłe inwestycje producentów w prace badawczo-rozwojowe - rzadko wprowadzane innowacje w markach producentów lub innowacje są łatwe do skopiowania,

- nikłe wsparcie marketingowe marek producenta - relacja budżetu reklamowego do realizowanych obrotów jest niewielka ${ }^{12)}$,

- wydatki producenta na obniżki cen jego marki stanowią dużą cześś budżetu promocji - to podnosi wrażliwość konsumentów na cenę i zachęca ich do zmiany marki, a także zmniejsza wiarygodność cen marek producentów (nie odnosi się to do promocji typu multi-packi),

- w konsekwencji występuje zjawisko „parytetu konkurujących marek".

Źródło: J.A. QUELCH, D. HARDING, op.cit., s. 48-50; T. LEAHY, LEAHY T., Branding - the Retailer's Viewpoint, [w:] J.M. MURPHY, Branding - A Key Marketing Tool, Macmillan, Houndmills 1993, s. 119-120; F. BERGES-SENNOU, Ph. BONTEMS, V. REQUILLART, Economic Impact of the Developmentof Private Labels, First Biennal Conference of the Food System Research Group, University of Wisconsin, Madison, 26-27.06.2003; How Can Manufacturers Defend Against Private Label?, „Information Resources”, 26.07.2004. 
odsetek takich uprzedzonych konsumentów bywa różny, ale generalnie zjawisko braku pełnego zaufania do marek handlowych jest powszechne.

Wspólne cechy produktów, w przypadku których marki handlowe zdobywają znaczące udziały rynkowe, przedstawia tab. 2.

Dostrzegając atrakcyjność niektórych rynków produktowych detaliści, nie bacząc na przywoływane ograniczenia w budowaniu silnej pozycji ich marek, podejmują skuteczne próby umacniania pozycji należących do nich marek. Przykładem nietypowego dla marek handlowych produktu mogą być wina, które w 2003 roku awansowały w amerykańskich supermarketach do miana drugiej w kolejności najszybciej rosnącej kategorii produktowej objętej markami handlowymi (wzrost sprzedaży w roku 2002 o 43\%). Można przy tym wskazać wiele przykładów ewidentnych sukcesów marek handlowych na tym rynku ${ }^{13)}$.

$\mathrm{Z}$ wielu względów korzystna dla sieci detalicznej strategia nadawania własnych marek nie jest możliwa do zastosowania przez każdego detalistę. Warunkiem skutecznego wprowadzenia na rynek marki korporacyjnej (której nazwa pokrywa się z nazwą sieci detalicznej) jest zdobycie przez sieć odpowiedniej reputacji. Wysoką renomą cieszą się przykładowo niektórzy detaliści brytyjscy, którzy obdarzani są niejednokrotnie większym zaufaniem, w porównaniu $\mathrm{z}$ takimi instytucjami, jak banki, policja czy kościół ${ }^{14)}$. Ele-

\section{Tab. 3. Czynniki związane z detalistą, sprzyja-} jące dominującej pozycji marki handlowej

- detalista cieszy się zaufaniem kupujących i posiada na tyle znaczące zasoby, że może sobie pozwolić na inwestycje w rozwój dobrych jakościowo marek handlowych;

- detalista sprawuje pełną kontrolę nad specyfikacją produktów oferowanych pod markami handlowymi, co gwarantuje stabilna jakość oferty - w porównaniu z markami producentów jakość marki detalisty jest wysoka i stale się poprawia;

- produkty oferowane pod marką handlową obecne są na rynku od wielu lat;

- oferta produktów pod markami handlowymi jest szero$\mathrm{ka}$;

oferowane marki handlowe obejmują kilka poziomów cenowych (w tym w segmencie premium);

- duża liczba sklepów w sieci danego detalisty;

- produktom oferowanym pod markami handlowymi gwarantowane jest znaczące wsparcie promocyjne (w tym w zakresie merchandisingu);

- detalistajest elementem stabilnego oligopolu, stąd sprzedaje wiodące marki producentów po relatywnie wysokich cenach;

- asortyment sklepu składa się z mniejszej liczby marek producentów (jest płytszy);

- mało promocji cenowych odnoszących się do marek producentów - detalista stosuje strategie „codziennie niskie ceny" (everyday low prices) ${ }^{15}$.

Źródło: J.A. QUELCH, D. HARDING, op.cit., s. 48-50; R. BATRA, I. SINHA, op.cit; ; L. de CHERNATONY, M. McDONALD, op.cit., s. 193; F. BERGES-SENNOU, Ph. BONTEMS, V. REQUILLART, op.cit.; S.K. DHAR, Why Store Brand Penetration Varies by Retailer, „Capital Ideas”, wiosna 1998; S.J. HOCH, How Should National Brands Think About Private Labels?, „Sloan Management Review”, wiosna 1996 mentami zwiększającymi zaufanie konsumentów do detalistów oraz oferowanych przez nich marek handlowych są m.in. gwarancje, szczegółowe informacje o produktach oferowanych pod tymi markami (wykraczające swym zasięgiem poza minimum określone normami prawnymi) oraz szybkie zmiany i modyfikacje receptur produktów.

Czynniki związane z samą siecią detaliczną, a wpływające na wielkość udziału w obrotach, jaki może przypaść markom handlowym, przedstawia tab. 3.

Wiele wskazuje na to, że pozycja rynkowa marek handlowych także w Polsce będzie się umacniać. Tym bardziej, że pozostałe sposoby uzyskiwania przez sieć detaliczną przewagi konkurencyjnej (niskie ceny, lokalizacja, wyjątkowa obsługa) wydają się powoli wyczerpywać swój potencjał generowania wartości dla kupujących.

dr Jacek Kall

Katedra Marketingu Produktu Akademia Ekonomiczna w Poznaniu

\section{PRZYPISY}

1) The Power of Private Label - A Review of Growth Trends Around the World, Executive News Report from AC Nielsen Global Services, AC Nielsen, lipiec 2003, s. 7.

2) Jak wykazują badania InfoScan z końca 2002 roku, w niektórych amerykańskich miastach, jak np. w Little Rock, Columbus czy Portland udział marek handlowych w rynku sięgał 20-25\%, a z drugiej strony, w Milwaukee czy Cleveland (położonym w tym samym stanie, co Columbus) tylko 11-13\%. Private Label Trends in the Supermarket Channel, ,Times\&Trends”, październik 2002, s. 18.

3) A. QUELCH, D. HARDING, Brands versus Private Labels - Fighting to Win, [w:] Harvard Business Review on Brand Management, HBS Press, Boston 1999, s. 26.

4) S.J. HOCH, How Should National Brands Think About Private Labels?, „Sloan Management Review”, wiosna 1996.

5) W USA, w przypadku podstawowych artykułów spożywczych marki handlowe kupuje ponad 3/4 gospodarstw domowych (w pozostałych produktach tylko $20 \%$ populacji). W Wielkiej Brytanii, wg badań przeprowadzonych w 2002 roku 52\% konsumentów deklaruje częste kupowanie marek handlowych, a tylko 5\% deklaruje, że nie kupuje ich nigdy. Badania wlasne autora, zrealizowane wśród konsumentów w hiper/supermarketach na terenie Poznania, dowodzą, że co najmniej połowa kupujących nabywa (choćby tylko sporadycznie) produkty pod markami handlowymi. The Truth About Brands: The Real Story on Private Label in the U.S., www.infores.com; Case Studies - Private Label Manufacturers Association, www.mori.com; badania własne; populacja: kupujący w hiper/supermarketach w Poznaniu; listopad 2002 $\mathrm{n}=600$, październik 2003, $\mathrm{n}=421$.

6) S.J. HOCH, op.cit.; Profile of Private Label, AC Nielsen, wrzesień 1999; M. MOGELONSKY, When Stores Become Brands, „American Demographics”, luty 1995; Bright Future for Private Label Across Europe, 15.11.1999, www.mori.com.

7) S. BURT, S. DAVIS, Follow my Leader? Lookalike Retailer Brands in Non-manufacturer-dominated Product Markets in the UK, „The International Review of Retail, Distribution and Consumer Research”, kwiecień 1999. 
8) The Power of Private Label, op.cit., s. 14.

9) Ibidem, s. 14.

10) Badania zrealizowane w listopadzie 2002 r. na próbie 428 kupujących w hiper/supermarketach w Poznaniu.

11) Polscy konsumenci wykazują obawy przed kupowaniem niektórych produktów świeżych, w przypadku których postrzegane ryzyko zakupu może być spore (mięso, wędliny), a także w przypadku produktów o silnym ładunku symbolicznym (np. piwo), produktów związanych z silnie odczuwanym ryzykiem funkcjonalnym (np. kosmetyki) oraz skomplikowanych produktów technicznych, w przypadku których konsumenci mogą wątpić w możliwości sieci wytworzenia dobra o wysokiej wartości użytkowej (np. sprzęt AGD oraz RTV).

12) W dziesięciu kategoriach produktów, w których najsilniejsze są marki handlowe, budżety reklamowe producentów brytyjskich, w relacji do realizowanych obrotów, są ponad 5-krotnie mniejsze, w porównaniu do dziesięciu kategorii produktów, w których marki handlowe są najsłabsze. G. RANDALL, Branding - A Practical Guide to Planning Your Strategy, Kogan Page, London 2000, s. 88.

13) Wiosną 2002 roku spore zamieszanie w branży winiarskiej było udziałem wina Two Buck Chuck, pochodzącego z cieszącej się nie najgorszą renomą winnicy Charles R. Shaw, oferowanego jako marka własna w sieci dyskontów Trader Joe's, w cenie 1,99 USD za butelkę. Wal-Mart wprowadził wino pod marką własną Alcott Ridge, dostarczane przez słynnego producenta win kalifornijskich, winnicę braci Gallo. Label Makes Its Mark, „Beverage Industry", czerwiec 2003; H. BEHAR, Retailers Embracing Private Label Wines, „Beverage Aisle”, 15.03.2003; Private Label Hit Spurs Wheeling and Dealing, „Beverage Industry", maj 2003; M. HOCHSTEIN, Wines for All Wallets, „Private Label Magazine”, lipiec-sierpień 2003.

14) Customer Loyalty \& Private Label Products, KPMG Global Consumer Markets, marzec 2000, s. 25.

15) Badania Ailawadiego, Neslina i Gedenka dowodzą, że kupowanie marek producentów w promocji cenowej (przeciętna obniżka rzędu 20-30\%) oraz kupowanie marek handlowych (w cenach o około 30\% niższych od marek producentów) to dwa odmienne zachowania, wywołane odmienną charakterystyką psychograficzną konsumentów. Kupujący marki handlowe poszukują głównie korzyści ekonomicznych; charakteryzuje ich wysoka świadomość cenowa oraz niska wrażliwość na jakość. Są to konsumenci lojalni wobec sklepu, a przy tym mało podatni na typowe działania promocyjne producentów. Sposobem dotarcia do nich są programy stałego klienta, podkreślanie relatywnie stałych, niskich cen oraz łatwości zakupu marek handlowych. W przypadku tego segmentu skuteczniejsza jest strategia codziennie niskich cen, niż akcyjnie prowadzone promocje cenowe, które wymagają planowania zakupów (są atrakcyjne tylko wtedy, kiedy konsument czerpie przyjemność z kupowania). Z kolei segment kupujących marki producentów w promocji oczekuje raczej korzyści hedonistycznych, czerpie większą przyjemność z robienia zakupów, charakteryzuje go impulsywność oraz silnie odczuwana potrzeba podporządkowania się oczekiwaniom innych. Ich gotowość do zmiany sklepów jest silniejsza, niż gotowość zmiany marek producenta. W przypadku tego segmentu korzystniejsza jest strategia akcyjnie prowadzonych promocji cenowych, niż codziennie niskie ceny. K.L. AILAWADI, S.A. NESLIN, K. GEDENK, Pursuing the Value-Conscious Consumer: Store Brands Versus National Brand Promotions, „Journal of Marketing”, styczeń 2001. 